\title{
Perspektif Baru Groupthink: Perbedaan Tingkat Pendidikan dalam Proses Pengambilan Keputusan Kelompok
}

\author{
MARLINDA IRWANTI ${ }^{1}$, DEDDY MUHARMAN² \\ ${ }^{1}$ Stikom Interstudi, 2 jurusan komunikasi, ${ }^{2}$ stikom LSPR \\ email: ${ }^{1}$ marlinda1610@gmail.com, ${ }^{2}$ deddy.m@lspr.edu
}

\begin{abstract}
This research is motivated by the phenomenon of groups of female who usually frequent and visible to see from even elementary schools until university. The interesting point of this research is, researchers interested in analyzing this phenomenon with questions, whether the difference in education level affects the decision-making process in the female group, adding the complexity of the pre-existing nature within the group members. This study uses interviews and focus group discussions to gather data that are expected to explain the above phenomena by using assumptions and symptoms of Groupthink theory itself. The results showed that there was no difference in the decisionmaking process of the different groups of the educational level, and other interesting findings that Groupthink does not occur in these groups. This happens because these groups did not shut down their point of view from outside influences, and also the absence of a formal group leader, and the persistence of high mutual understanding of his fellow group members.
\end{abstract}

Keywords: Groupthink, communication, decision-making, group

\begin{abstract}
Abstrak. Penelitian ini dilatarbelakangi oleh fenomena kelompok kelompok wanita yang biasanya sering muncul dan terlihat dari mulai sekolah-sekolah dasar sampai universitas. Hal yang kemudian membuat peneliti tertarik menganalisa fenomena ini adalah sebuah pertanyaan, apakah perbedaan tingkat pendidikan berpengaruh terhadap proses pengambilan keputusan didalam kelompok wanita tersebut, mengingat kompleksitas yang sudah ada sebelumnya dalam diri para anggota kelompok. Penelitian ini menggunakan interview dan focus group discussion untuk mengumpulkan data-data yang diharapkan dapat menjelaskan fenomena diatas dengan menggunakan asumsi dan gejala-gejala dari teori Groupthink itu sendiri. Hasil penelitian menunjukkan bahwa tidak terdapat perbedaan dalam proses pengambilan keputusan dari kelompok-kelompok yang berbeda tingkat pendidikan ini, dan temuan lain yang menarik bahwa Groupthink tidak terjadi pada kelompok-kelompok ini. Hal ini terjadi karena kelompok-kelompok yang menjadi narasumber tidak menutup diri terlalu kuat dari pengaruh luar, juga karena tidak adanya pemimpin kelompok secara formal dan masih adanya rasa saling pengertian yang tinggi dari sesama anggota kelompok.
\end{abstract}

Kata Kunci: Groupthink, komunikasi, pengambilan keputusan, kelompok

\section{Latar Belakang}

Manusia sebagai makhluk sosial, memiliki satu kebutuhan dasar, dan memerlukan interaksi antara orang lain. Interaksi ini penting karena manusia memiliki banyak kebutuhan, dan tidak dapat dipenuhi oleh dirinya sendiri. Sepanjang interaksi, manusia tahu satu sama lain dan secara alami akan memilih yang berpotensi untuk memiliki hubungan yang baik dan kuat dalam hidup mereka.
Aristoteles memiliki penjelasan yang unik tentang hal ini. Menurut Charalambos Ierodiakonou dalam bukunya, The Psychology of Aristoteles, The Philosopher: A Psychoanalytic Therapist's Perspective, ia menyebut manusia sebagai "zoon oikonomikon", dalam bagian lain "zoon politicon," dan di tempat lain "zoon koinonikon," yang berarti "hewan "berkaitan dengan masalah rumah tangga, yang terlibat dalam urusan politik, dan umumnya menjadi sosial (dan ramah).

Received: 27 Februari 2015, Revision: 6 April 2015, Accepted: 22 Juni 2015

Print ISSN: 0215-8175; Online ISSN: 2303-2499. Copyright@2015. Published by Pusat Penerbitan Universitas (P2U) LPPM Unisba Terakreditasi SK Kemendikbud, No.040/P/2014, berlaku 18-02-2014 s.d 18-02-2019 
Masih dalam bukunya yang sama, Charalambos Ierodiakonou menjelaskan apa yang dikatakan Aristoteles, pandangan analog diungkapkan oleh Aristoteles dalam pembahasannya tentang faktor-faktor penentu persahabatan: Isotes - homeotes - Filotes (kesetaraan - kesamaan - persahabatan) yang berarti bahwa dalam kondisi yang sama dan kepribadian yang sama ciri-ciri persahabatan yang lebih baik akan dibentuk.

Salah satu kelompok sosial yang sering terlihat adalah sekelompok remaja bahkan dewasa yang terdiri dari wanita. Kita bisa melihat jenis kelompok ini dimana-mana, mulai dari sekolah, perguruan tinggi, sampai di lingkungan kantor. Dengan latar belakang yang kemungkinan hampir sama, seperti dijelaskan di atas, kelompok-kelompok ini melanjutkan, bertahan hidup, atau mungkin hilang, karena proses-proses sosial yang terjadi antara anggota atau dengan kelompok lain.

Dibandingkan dengan kelompok pria, kelompok wanita memiliki karakteristik yang berbeda. Menurut brainfitnessforlife.com, salah satu perbedaannya adalah wanita diakui untuk memiliki keterampilan komunikasi yang lebih baik dan kecerdasan emosional dibandingkan pria. Wanita cenderung berorientasi kelompok, dan cenderung mencari solusi dengan berbicara melalui isuisu.

Informasi ini menjelaskan mengapa wanita cenderung memiliki kelompok dibandingkan dengan pria. Mereka merasa lebih kuat dalam kelompok mereka. Di bagian lain dari artikel, brainfitnessforlife. com juga menjelaskan karena wanita cenderung memiliki sistem limbik yang dalam dan lebih besar dari pria, mereka lebih berhubungan dengan perasaan mereka dan lebih baik dalam mengekspresikan emosi mereka. Hal ini membuat wanita lebih baik dalam berhubungan dengan orang lain, tapi sayangnya juga lebih rentan terhadap berbagai jenis depresi.

Menurut Elizabeth Aries dalam bukunya, Men and Women in Interaction: Reconsidering the Differences: Reconsidering, Daniel Maltz dan Borker Ruth menjelaskan temuan lain yang menarik. Maltz dan Borker menarik suatu temuan yang dimulai pada usia 3 tahun, anak-anak cenderung memisahkan diri dalam kelompok bermain mereka berdasarkan jenis kelamin, sebuah pola yang terus tumbuh. Mereka berpendapat bahwa pria dan wanita tumbuh dalam subkultur yang berbeda yang memiliki aturanberbicara yang berbeda. Karena pria dan wanita berinteraksi dalam konteks sosial yang terpisah dan berbeda, mereka belajar wanita dapat saling memahami dengan lebih baik.

Hal senada juga dijelaskan oleh vemale. com, menurut mereka, pria cenderung spontan dan mandiri, dibandingkan dengan wanita yang lebih memilih untuk berkumpul dan menyenanangi kompleksitas yang diperlukan untuk melakukan hal-hal yang lebih detail. Dari penjelasan tersebut, kita dapat menyimpulkan bahwa wanita merasa lebih kuat ketika mereka berada di grup, dan kadang-kadang hal ini membuat mereka lebih nyaman.

Referensi lain yang menarik dalam hal ini adalah, menurut salah satu artikel di female.kompas.com, Barney Stinson dari serial How I Met Your Mother, yang memiliki teori "efek cheerleader", yang menjelaskan bagaimana ketika para wanita beraksi dalam kelompok, mereka semua tampak sangat cantik dan seksi, namun jika dilihat secara individual, justru terlihat normal.

Dari referensi tersebut, kita bisa melihat bagaimana unik dan kelompok wanita yang berbeda dibandingkan dengan pria. Dalam referensi lain, komplikasi dalam kehidupan remaja dapat menambahkan kompleksitas pada wanita khususnya dalam kelompok. Diterbitkan oleh Yayasan Psikologi Kanada di salah satu buku mereka, Straight Talk About teen, sosiolog Kanada Reginald Bibby telah mengamati pemuda Kanada sejak 1980an. Setiap kali ia meminta remaja apa yang paling penting bagi mereka, persahabatan dan kebebasan muncul di urutan teratas dari daftar.

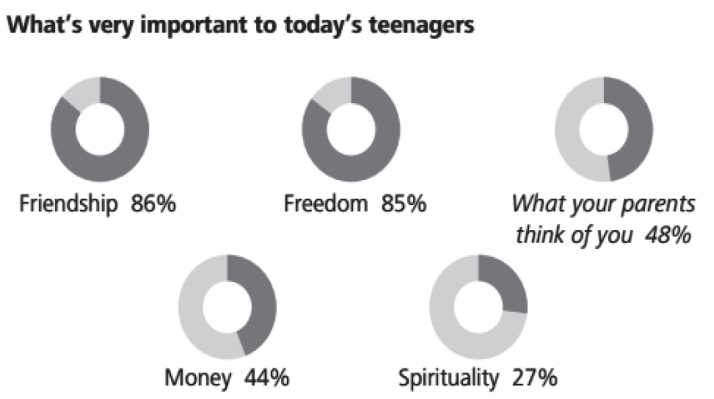

Gambar 1. Yayasan Psikologi Kanada, Straight Talk about Teen

Aktivitas sosial telah menjadi pengalaman baru mereka, kadang-kadang remaja tidak bergaul dengan baik. Masih dari Kanada, Dr Bibby memiliki survei dari apa yang membuat remaja khawatir, yang 
diterbitkan oleh Project Canada Books. Dan hasil surveinya adalah sebagai berikut:

\begin{tabular}{lc} 
ISSUE & \% VERY CONCERNED \\
\hline School pressure & 75 \\
What to do when finished school & 68 \\
Lack of money & 56 \\
Not enough time & 56 \\
Losing friends & 55
\end{tabular}

\section{Gambar 2. Yayasan Psikologi Kanada,} Straight Talk about Teen

Kehidupan sehari-hari bagi remaja adalah sekolah. Jadi kita tidak terkejut bahwa apa yang terjadi di sekolah, bisa menjadi tekanan bagi mereka, dan berada di kelompok bisa menjadi salah satu solusi untuk menangani hal ini. Untuk menangani hal-hal yang terjadi dalam kelompok, seseorang harus memiliki keputusan, untuk setiap pilihan atau keputusan yang perlu diambil. Entah itu tentang tempat berkumpul di sore hari, atau apa subjek atau kursus apa yang perlu diambil. Untuk menjelaskan bagaimana sebuah kelompok kecil mengambil suatu keputusan, ada satu teori komunikasi berbicara tentang hal ini, yaitu Groupthink Theory.

Dijelaskan oleh West - Turner dalam buku mereka, Introducing Communication Theory, teori ini diperkenalkan oleh Irving Janis dalam bukunya, Victims of Groupthink (1972), Groupthink adalah cara kelompok melakukan musyawarah yang meminimalkan konflik dan menekankan perlunya kebulatan suara

Meskipun dalam pengembangan teori, Janis menganalisis beberapa hal yang berkaitan dengan isu-isu politik pemerintah, Groupthink masih bisa dipakai sebagai alat jika kita ingin menganalisis sebuah kelompok kecil, terutama tentang bagaimana kelompok mengambil keputusan mereka. Karena menurut Janis, anggota kelompok mudah gagal untuk merenungkan intuisi mereka, dan keinginan mereka untuk sebuah kesepakatan dibayang-bayangi oleh perhitungan penting dari keputusan mereka.

Masih dalam buku yang sama, oleh West-Turner, Janis menyebutkan tiga asumsi dari Teori Groupthink; Pertama, Kondisi dalam kelompok mempromosikan kekompakan tinggi. Semakin kuat kelompok, kekompakan juga semakin tinggi. Hubungan antara anggota yang pasti tinggi. Kekompakan adalah salah satu dari perilaku dan membentuk kinerja tim. Kekompakan didefinisikan sebagai sejauh mana anggota kelompok bersedia untuk bekerja sama. Ini adalah rasa kebersamaan kelompok.

Kedua, pemecahan masalah kelompok pada dasarnya merupakan suatu proses terpadu. Jadi, menyadari situasi ini, anggota kelompok, pada dasarnya berjuang untuk mendapatkan kebersamaan tersebut. Dennis Gouran (1998) mencatat bahwa kelompok-kelompok yang rentan terhadap keterbatasan anggota, yang berarti bahwa anggota kelompok memegang masukan atau informasi mereka sendiri daripada risiko penolakan dari grup. Menurut Gouran, ketika anggota kelompok berkontribusi, memiliki perasaan takut ditolak, mereka cenderung untuk mementingkan dan melindungi kelompok daripada isu-isu yang sedang dipertimbangkan. Dan anggota kelompok lebih termotivasi untuk mengikuti pemimpin mereka saat pengambilan keputusan diwaktu yang diperlukan.

Jika kita dapat menghubungkan asumsi ini dengan kehidupan remaja, kita dapat melihat dengan jelas bahwa beberapa remaja takut terhadap penolakan. Mereka tahu bahwa hidup mereka sudah rumit dengan sekolah dan hal-hal lain, dan karena itu, mereka membutuhkan teman mereka dan keberlanjutan dalam kelompok mereka, jadi, daripada harus keluar dari grup, beberapa akan memilih untuk mengikuti pendapat pemimpin mereka ketika mereka perlu mengambil keputusan.

Asumsi ketiga adalah, kelompok dan proses pengambilan keputusan kelompok sering kompleks. Asumsi ini bergantung pada sifat kelompok dalam pemecahan masalah dan tugas biasanya sulit atau rumit. Dalam perjalanan menuju pengambilan keputusan, kelompok harus berurusan dengan negosiasi, dan kompleksitas yang sulit dalam kelompok, negosiasi akan terjadi. Seorang anggota dalam kelompok kecil harus tetap menghargai banyak substitusi dan pilihan yang tersedia bagi mereka dan dapat memutuskan alternatif yang akan diambil. Dan juga, anggota harus tidak hanya menyadari pilihan yang ada di mereka sendiri, tetapi juga orang-orang yang memberikan masukan. Fokus dalam tulisan ini, melihat setiap tingkat pendidikan yang berbeda dapat memengaruhi anggota tim untuk mengambil keputusan mereka dan rumusan masalahnya mencoba melihat perbedaan dalam proses pengambilan keputusan yang terjadi pada perbedaan tingkat pendidikan. 
Dalam beberapa gejala, memang kelompok Darvenzev sebagai kelompok termuda (SMP) memang menunjukkan tingkat egoisme lebih tinggi dari kelompok yang lebih tua, tapi dalam beberapa hal, mereka masih mampu mempertahankan integritas kelompok untuk memberikan rasa pemahaman untuk anggota lain dengan alasan yang baik, yaitu untuk menghindari pecahnya grup.

\section{Groupthink Theory}

Dalam buku West-Turner, dengan penjelasan Irving Janis tentang teori Groupthink, sekilas, Janis menjelaskan bahwa kelompok-kelompok yang sangat kohesif sering gagal untuk mempertimbangkan alternatif untuk tindakan mereka. Ketika anggota kelompok berpikir sama dan tidak mempertimbangkan pandangan sebaliknya, mereka juga tidak mungkin untuk berbagi ide yang tidak populer atau berbeda dengan orang lain. Groupthink menunjukkan bahwa kelompok-kelompok ini cenderung membuat keputusan yang bersifat dini, dan beberapa di antaranya memiliki konsekuensi yang abadi dan tragis. Menurut Janis, anggota kelompok gagal untuk mempertimbangkan intuisi, dan bias dalam keinginan harmoni mereka yang mendominasi penilaian kritis keputusan sendiri.

Bagian penting lainnya dari teori Groupthink adalah kekompakan. Kekompakan didefinisikan sebagai sejauh mana anggota kelompok bersedia untuk bekerja sama. Ini adalah rasa kebersamaan dalam kelompok. Kohesi muncul dari sikap suatu kelompok, nilai-nilai, dan pola perilaku, para anggota yang sangat tertarik pada sikap, nilai-nilai, dan perilaku anggota lain sehingga lebih mungkin untuk dipanggil kohesif.

Salah satu hal yang menarik perhatian adalah bahwa kohesi berbeda dari satu kelompok ke kelompok lain, dan berbagai tingkat kohesi menghasilkan hasil yang berbeda. Dalam beberapa kelompok, kohesi dapat menyebabkan perasaan positif tentang pengalaman kelompok dan anggota kelompok lainnya. Kelompok yang sangat kohesif mungkin juga lebih bergairah tentang tugastugas mereka dan merasa ber hak untuk melakukan tugas tambahan. Singkatnya, kepuasan yang lebih besar dikaitkan dengan peningkatan kekompakan dalam kelompok.

Meskipun keuntungan jelas terlihat, kelompok yang sangat kohesif juga dapat membawa insiden yang mengganggu. Janis percaya bahwa kelompok-kelompok dapat mencapai derajat tinggi kekompakan; euforia ini cenderung menutupi pendapat dan alternatif lainnya. Anggota kelompok mungkin tidak bersedia untuk mengungkapkan keraguan tentang solusi. Dan anggota bahkan menyensor komentar mereka sendiri tanpa termotivasi untuk melakukan hal yang sebaliknya.

Inilah yang membuat setiap pengambilan keputusan dalam kelompok wanita kadang-kadang menarik. Beberapa keputusan harus mengalami banyak diskusi dan perdebatan. Tetapi pada akhirnya, anggota masih sadar tentang kohesifitas mereka, dan memungkinkan pemimpin yang dominan mengambil keputusan. Namun pemimpin atau orang yang dominan dalam kelompok harus berhati-hati dalam perjalanan memimpin kelompok, karena dapat menyebabkan kurangnya kepemimpinan yang tidak memihak, yang berarti bahwa anggota kelompok yang dipimpin oleh orang-orang yang memiliki kepentingan pribadi dalam hasilnya.

Dua gejala khusus yang ada dalam kategori ini: ilusi kekebalan dan keyakinan dalam moralitas yang melekat pada kelompok. Ketika sebuah kelompok berpikiran tertutup, dan mengabaikan pengaruh luar pada kelompok. Dua gejala yang dibahas oleh Janis dalam kategori ini adalah stereotip hubungan external dari kelompok dan rasionalisasi kolektif. Dan yang terakhir adalah, tekanan terhadap keseragaman, bisa sangat besar bagi beberapa kelompok. Janis percaya bahwa beberapa kelompok yang pergi bersama untuk bergaul mungkin dalam proses pengaturan diri untuk Groupthink.

\section{Umur Atau Tingkat Pendidikan Sebagai Faktor Kognitif}

Menurut John Bissell Carroll dalam bukunya, Human Cognitive Abilities: A Survey of Factor-Analytic Studies, kognitif adalah suatu proses yang mengacu pada satu atau serangkaian tindakan yang dioperasikan untuk menghasilkan beberapa hasil. Sebuah proses kognitif dimana mental dioperasikan untuk menghasilkan beberapa tanggapan. Isi mental yang mungkin berupa pernyataan atau encoding baik dari rangsangan eksternal atau gambar, pengetahuan, aturan, dan bahanbahan yang sama dari jangka pendek atau memori jangka panjang.

Tanggapan dapat berupa rahasia atau terang-terangan. Dalam konteks pengujian mental, hanya respon yang diamati yang diterima sebagai data, meskipun mungkin 
berguna, untuk menjelaskan data tersebut dan mengembangkan konstruk hipotetis mengenai tanggapan rahasia.

Untuk membandingkan kelompok perempuan yang akan diteliti dalam penelitian ini, dibagi menjadi tiga kelompok usia pendidikan, SMP, SMA dan perguruan tinggi / universitas, teori kognitif menggunakan teori yang berbeda. Dimana SMP dan kelompok SMA dapat disertakan dalam periode masa remaja, kelompok universitas dapat dikategorikan ke dalam tahap awal masa dewasa.

Menurut Sugarman,dalam Life-span Development: Frameworks, Accounts and Strategies, diadaptasi dari Newman \& Newman, karakteristik remaja (12-18 tahun) adalah; kematangan fisik, operasi formal, perkembangan emosional, keanggotaan dalam kelompok sebaya, dan hubungan seksual.

Berbagai saluran pelepasan ketegangan diciptakan oleh sekelompok remaja untuk dapat mengurangi kecemasan yang dialami, misalnya, mendengarkan radio dengan suara keras, tertawa terbahak-bahak, tinggal dengan sesama teman, dan sebagainya. Selain itu, kelompok ini juga mengembangkan bahasa yang sulit, yang khusus dan hanya dipahami oleh mereka sendiri. Hal-hal tersebut di atas adalah gejala yang biasa muncul dalam kelompok remaja pada umumnya.

Sementara itu, di masa dewasa awal, (18-22 tahun) karakteristik sikap lebih kepada otonomi dari orang tua, identitas gender, moralitas diinternalisasi, dan pilihan karir. Beberapa fitur di masa dewasa awal adalah masa penyesuaian dengan cara hidup yang baru dan memanfaatkan kebebasan tumbuh. Awal masa dewasa adalah periode perkembangan fisik berikut usia seseorang, yang merupakan awal motivasi dewasa untuk mencapai sesuatu yang begitu besar yang didukung oleh kekuatan fisik.

Hal ini jelas terkait dengan apa yang dijelaskan dalam Groupthink, di mana masih adanya rasa takut yang dirasakan karena penolakan ketika anggota memiliki pendapat yang berbeda dari mayoritas anggota yang lain. Ternyata keinginan untuk masih terlihat eksis dan berkembang di masa dewasa awal yang menjelaskan bagaimana akhirnya para anggota kelompok perempuan masih bertahan dalam kelompok meskipun sudah mulai memasuki masa dewasa awal.

Penelitian ini menggunakan metode kualitatif dengan pengumpulan data primer dengan cara wawancara, (C. Daymon dan Holloway, I). Narasumber dalam penelitian ini dipilih berdasarkan karakter-karakter seperti: masuk dalam satu kelompok tingkat pendidikan (SMP, SMA, dan Mahasiswa), kemudian kelompok tersebut harus beranggotakan wanita, dan terdiri dari minimal 4 orang, sehingga dapat terlihat apakah ada perbedaan dalam proses pengambilan keputusan karena perbedaan tingkat pendidikan kelompokkelompok wanita tersebut.

Penelitian dilakukan dari September sampai Desember 2014 dengan lokasi di daerah Bekasi dan Depok. Batasan dalam penelitian ini adalah hanya terbatas meneliti kelompok wanita saja, dan dalam hubungannya dengan kompleksitas yang terjadi terutama dalam proses pengambilan keputusan didalam kelompok. Berikut ini adalah analisa hasil penelitian.

Kelompok "Darvenzev" yang merupakan perwakilan kelompok dari tingkat pendidikan SMP. Kelompok ini terdiri dari Fera, Farah, Rifda, Novita, Sekar, dan Zeta, dari SMP 17 Bekasi. Nama "Darvenzev" berasal dari singkatan nama-nama mereka. Untuk kelompok SMA, terpilih "Minion", dari SMA Tugu Ibu Depok. Kelompok ini terdiri dari Woro, Cantika, Fesya, dan Safira. Alasan menggunakan nama Minion karena mereka merasa banyak yang terjadi dalam kelompok mereka sesuai dengan keributan dalam kelompok Minion dalam film "Despicable Me". Dan terakhir, adalah kelompok yang berasal dari pendidikan tingkat perguruan tinggi, yang diwakili oleh kelompok "Reg", yang namanya diambil dari Program Reguler, di Fakultas Komunikasi, Universitas Indonesia, Depok. Kelompok ini terdiri dari Inta, Gesha, Raudah, Maudy, Oca, dan Yasmin.

Tingkat pendidikan merupakan hal yang wajar dalam kehidupan sehari-hari mereka. Setiap tingkat memiliki karakteristik dan tantangan yang berbeda. Dalam penelitian ini, akan dianalisa tiga tingkat pendidikan yang berbeda. Alasan mengapa pemilihan kelompok informan mulai dari tingkat pendidikan SMP, karena di tingkat pendidikan sebelumnya, SD dan TK, proses pengambilan keputusan lebih rumit daripada tingkat pendidikan di atas, dan juga sebagai informan, dikhawatirkan pertanyaan tidak terjawab dengan gambaran situasi rinci sesuai dengan pertanyaan penelitian.

Menurut Piaget, dalam Theory of Development, dapat dilihat apa yang menyebabkan kelompok informan SMP (12-15 
tahun) dapat menjawab pertanyaan dengan lebih relevan. Dari buku Developmental Psychology: Anak dan Remaja: David Reed Shaffer, Katherine Kipp, Piaget menyatakan bahwa kelompok usia 7-11 tahun, yang disebut sebagai The Concrete-Operational Stage terbatas karena mereka dapat menerapkan skema operasional mereka hanya ke objek, situasi, atau kejadian yang nyata atau dibayangkan. Kesimpulan transitif The Concrete-Operational Stage, misalnya, cenderung akurat hanya untuk benda-benda nyata yang (atau telah) hadir secara fisik. Tujuh sampai 11 tahun usia belum bisa menerapkan logika relasional secara abstrak seperti penanda Xs, Ys, dan Zs yang kita gunakan dalam aljabar. Ini berarti bahwa kelompok tersebut masih belum mampu memberikan argumentasi dan penjelasan yang cukup handal dalam penelitian yang kompleks.

Hal yang sama, tetapi menjadi alasan yang berbeda mengapa batas atas tingkat pendidikan yang dibahas dalam penelitian ini sampai hanya sebuah perguruan tinggi dari Strata 1 . Di tingkat pendidikan selanjutnya, Strata 2, sebagian besar siswa juga telah menjadi karyawan atau sudah bekerja, itu membuat hidup mahasiswa S2 menjadi lebih kompleks dan lebih banyak dipengaruhi oleh hal-hal lain di luar dunia pendidikan. Kemungkinan penelitian dalam kategori ini bisa dilanjutkan dalam penelitian kemudian.

Hasil analisa dalam penelitian ini didasarkan pada konsep dan penjelasan teori Groupthink yang dijelaskan oleh Irving Janis, hal-hal yang membuat Groupthink terjadi dan gejala Groupthink itu sendiri. Hal ini ditunjukkan dengan lebih jelas pada gambar di bawah. Diambil dari buku Introducing Communication Theory, West-Turner, yang mengutip dari A Psychological Analysis of Conflict, Choice, and Commitment by Irving L. Janis and Leon Mann;

Dari gambar 3, dapat dilihat bahwa ada hal-hal tertentu yang secara sengaja atau tidak sengaja membentuk dan mengarahkan proses Groupthink. Lalu, ada tanda-tanda Groupthink itu sendiri yang dapat menyebabkan proses pengambilan keputusan menjadi kurang sempurna. Di bawah ini adalah analisa berdasarkan kondisi yang membentuk proses Groupthink dan tanda-tanda yang ditunjukkan Groupthink, berdasarkan hasil wawancara dengan informan yang telah disebutkan sebelumnya.

\section{Kondisi Anteseden Groupthink}

Menurut Janis, ada tiga kondisi yang memromosikan Groupthink; kekompakan yang tinggi dari kelompok dalam proses pengambilan keputusan, karakteristik struktural tertentu, dan tekanan internal / eksternal, yang akan dianalisa di bawah ini;

\section{Kekompakan kelompok}

Kohesivitas kelompok dibentuk dari berbagai hal, mulai dari bagaimana kelompok dibentuk, sampai hal-hal apa yang membuat kelompok akrab. Dari jawaban para narasumber, dapat disimpulkan bahwa pertemuan dengan intensitas tinggi dan faktor preferensi yang sama dapat menyebabkan kecenderungan seseorang mencari orang lain dan kemudian membentuk kelompok. Hal ini sesuai dengan yang disampaikan oleh Janis sendiri dalam buku Introducing Communication Theory oleh West-Turner, Irving Janis, dalam bukunya, Victims of Groupthink (1972), menjelaskan apa yang terjadi dalam kelompok di mana anggota kelompok sangat menyetujui pendapat satu

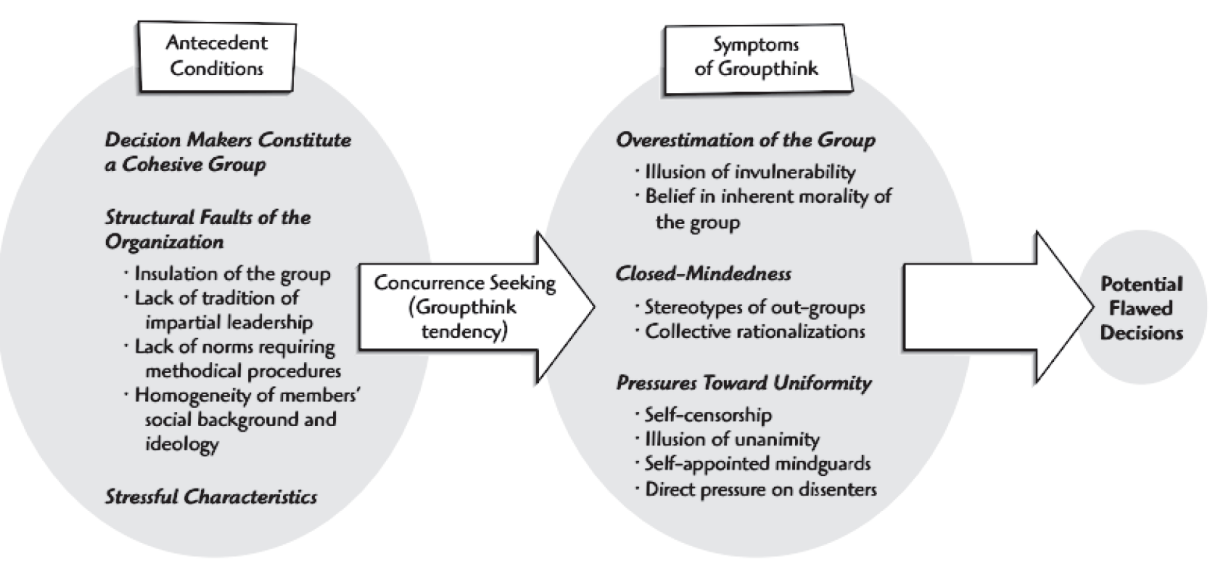

Gambar 3

Introducing Communication Theory 
sama lain.

Selain itu, kekompakan yang terjadi karena pola pikir yang sama, kesenangan, dan lokasi tempat tinggal juga sesuai dengan yang dijelaskan oleh John F Cragan, Chris R Kasch, dan David W. Wright dalam bukunya Small Group Communication, Theory, Process, and Skill. Mereka merumuskannya dalam Resep kohesif No 3; Interaksi berfokus pada komunikasi tim, kepercayaan, dan kemampuan memecahkan masalah; ditunjukkan oleh masing-masing kelompok, maka setidaknya lima peran utama yang dimainkan dalam kelompok, yang juga ditunjukkan oleh masing-masing kelompok

\section{Faktor Struktural}

Menurut Irving Janis, karakteristik struktural tertentu, atau kesalahan-kesalahan yang terjadi, dapat mempromosikan Groupthink. Dalam hal ini, ada beberapa pertanyaan untuk memperkuat dan menunjukkan proses bagaimana Groupthink terjadi.

Selain pengaruh dari pihak luar, kepemimpinan kelompok yang memiliki kecenderungan pribadi juga menjadi bagian dari faktor-faktor struktural. Dalam penelitian ini, semua kelompok tidak memiliki pemimpin resmi, karena karakteristik kelompok yang bersifat informal, sehingga faktor ini tidak terjadi dalam kelompok tersebut.

Sebuah kesalahan struktural akhir yang dapat menyebabkan Groupthink adalah gagalnya proses pengambilan keputusan dan kesamaan anggota kelompok. Gagal untuk mempertahankan norma-norma yang sebelumnya menjadi bahan evaluasi masalah dapat menumbuhkan Groupthink. Dari jawaban para narasumber dapat dilihat bahwa tidak ada kekurangan dalam prosedur pengambilan keputusan, meskipun dalam beberapa contoh, masih ada beberapa anggota kelompok yang tidak setuju dengan anggota lain, tetapi untuk menjaga integritas kelompok, anggota kelompok yang tidak setuju dengan pendapat kelompok dapat menerima keputusan kelompok.

\section{Tekanan Kelompok}

Selanjutnya, apa yang dapat dilihat dari kondisi Groupthink adalah tekanan terhadap kelompok, seperti tekanan kelompok internal dan eksternal. Pertanyaan yang diajukan adalah apakah ada tekanan untuk kelompok, dan jika ada, apakah itu berasal dari dalam atau di luar kelompok. Seperti yang dinyatakan oleh Janis, hampir semua kelompok juga mencari dukungan satu sama lain sebagai dukungan moral selama masa krisis, dan mungkin cenderung setuju dengan ide-ide untuk mendapatkan solusi, namun, dari semua kelompok diatas, tekanan yang dirasakan lebih kepada "tekanan positif", misalnya sebagai kebaikan yang diusulkan, atau jika ada tekanan yang menjengkelkan, selama kelompok merasa tujuannya adalah baik, kelompok tidak akan terpengaruh.

Kesimpulan dari kondisi-kondisi yang memengaruhi Groupthink, berdasarkan wawancara dari tiga kelompok, semua kelompok memang memiliki kohesi tinggi, karena didasarkan pada kepentingan bersama, jadwal, hingga kedekatan tempat tinggal. Namun, persyaratan kedua Kondisi pembentuk Groupthink tidak terlihat, karena tidak ada kelompok yang memiliki pemimpin resmi, jadi jika ada kecenderungan pribadi yang menonjol, yang dipandang sebagai ekspresi pribadi anggota, bukan kelompok. Hal ini dimungkinkan karena pada awalnya, Irvin Janis melakukan penelitian tentang Groupthink didasarkan pada kelompok formal yang memiliki struktur yang jelas. Sementara prasyarat ketiga Kondisi yang mempengaruhi Groupthink adalah tekanan kelompok, memang terjadi pada semua kelompok, terutama tekanan yang diterima dari luar kelompok. Namun, seperti yang sudah disebutkan di atas, tekanan-tekanan tersebut lebih bersifat positif, dalam arti memberikan masukan, saran, dan informasi yang berguna.

Dari tiga kelompok yang diteliti, tidak terlihat adanya upaya membentuk Groupthink, karena, dari semua jawaban, tidak terlihat adanya kecenderungan negatif yang dapat menyebabkan keputusan yang tidak maksimal atau gagal, seperti yang dijelaskan Irving Janis di Teori Groupthink. Dan untuk menjawab rumusan masalah penelitian, belum terlihat adanya perbedaan sikap dari masing-masing kelompok, yang mengacu pada perbedaan tingkat pendidikan. Setiap kelompok menunjukkan kondisi yang sama dalam menanggapi semua tekanan dan situasi yang terjadi pada kelompok.

\section{Gejala Groupthink}

Gejala Groupthink terbentuk dari upaya berlebihan kelompok dan anggota kelompok untuk mencapai kesepakatan. Gejala-gejala Groupthink muncul ketika anggota kelompok menjadi termotivasi untuk menghindari 
penilaian yang terlalu keras dalam penilaian mereka dari para pemimpin mereka dalam kelompok. Anggota akan melakukan kritik yang lembut untuk menghindari konflik, dan untuk mendapatkan konsensus, pada setiap isu-isu penting. Ada delapan gejala Groupthink, yang terbagi dalam tiga kategori;

\section{Pengharapan Yang Terlalu Tinggi Dari Grup}

Pengharapan yang terlalu tinggi dari Grup atau kelompok termasuk perilaku yang mempercayai bahwa ada sesuatu yang lebih. Dua gejala dalam kategori ini adalah: ilusi kekebalan dan keyakinan dalam moralitas yang melekat pada kelompok

Ilusi kekebalan didefinisikan sebagai keyakinan kelompok bahwa kelompok ini cukup istimewa untuk mengatasi hambatan atau masalah. Kelompok ini percaya mereka tak terkalahkan. Ada beberapa pertanyaan yang mencoba menjelaskan ini tentang gejala ini, pertama, apakah kelompok percaya bahwa kelompok ini begitu besar, sehingga bisa mengatasi semua rintangan, dan tentang keyakinan dalam moralitas yang melekat pada kelompok, di mana Kelompok merasakan sendiri untuk menjadi baik, percaya bahwa pengambilan keputusan mereka harus, karena itu, maka bisa dikatakan sudah baik.

Norris M Haynes dalam buku Group Dynamics, Basic and Pragmatics for Practitioners menyebutkan bahwa kepercayaan adalah tahap ketiga dari babak pembangunan grup, yang dimulai dengan munculnya rasa saling percaya dan kekompakan dalam anggota. Keyakinan kelompok meningkat sebagai anggota mulai percaya bahwa anggota sedang jujur tentang apa yang mereka rasakan dan percaya. Ada rasa bahwa anggota kelompok lebih asli dan dipercaya. kohesi Kelompok meningkat, yang berarti bahwa anggota kelompok merasa lebih terhubung.

\section{Pikiran yang tertutup}

Ini adalah karakter kedua gejala Groupthink, dimana kelompok mengabaikan pengaruh dari luar terhadap kelompok, dan merasa bahwa apa pun yang terjadi dalam kelompok mereka adalah yang terbaik. Ada dua poin dalam karakter ini, Out-group Stereotip dan Rasionalisasi Kolektif.

Out-group Stereotip adalah ketika kelompok memiliki persepsi tertentu terhadap saingan atau musuh. Stereotip ini menyoroti fakta bahwa salah satu dari para pesaingnya yang terlalu lemah atau terlalu bodoh. Rasa percaya diri yang berlebihan kadang-kadang mengarah ke asumsi ini.

Jawaban para narasumber juga beragam, mempertimbangkan cukup banyak input yang berupa umpan balik positif, menganggap sebagai motivasi dan berfungsi sebagai dasar untuk meningkatkan kualitas kelompok, terutama dalam konteks akademik di sekolah, walaupun kadang-kadang masih menerima pengaruh dari luar, namun pada saat ada masalah dalam kelompok, tetap mempertahankan integritas kelompok menjadi prioritas.

Poin kedua adalah rasionalisasi kolektif, di mana anggota kelompok mulai mengabaikan saran yang mungkin mendorong mereka untuk meninjau pendapat dan tindakan mereka sebelum mereka mencapai keputusan akhir mereka. Setelah merasa memiliki keputusan terbaik, kelompok terkadang tidak mau menerima dan mengabaikan masukan dari pihak lain. Salah satu kelompok, dari hasil wawancara, terlihat bahwa pendapat internal kelompok adalah yang paling penting, tidak peduli apa pendapat orang luar, walaupun tetap saja masih memiliki pertimbangan yang logis untuk input eksternal.

\section{Tekanan Terhadap Keseragaman}

Sementara karakter ketiga Gejala Groupthink adalah tekanan terhadap keseragaman, yang secara singkat berarti "pergi bersama untuk bergaul", yang menunjukkan kedekatan, kebersamaan terus menerus di antara anggota kelompok, dan masing-masing mempertahankan integritas kelompok, yang pada akhirnya berakhir di mana kelompok memiliki kecenderungan untuk menyesuaikan sifat Groupthink

Ada 4 poin utama karakter ini, yang merupakan self-censorship, ilusi kebulatan suara, kehadiran diri pikiran penjaga yang ditunjuk, dan tekanan langsung pada para pembangkang.

Dalam gejala self-censorship, dijelaskan bahwa anggota kelompok dalam proses penyaringan pendapat mereka sendiri dalam rangka mempertahankan integritas kelompok. Para anggota akan meminimalkan keraguan mereka untuk menjadi lebih tertarik pada pendapat bersama-sama. Dengan alasan untuk menghindari konflik, menemukan kenyamanan satu sama lain, sehingga mengalahkan semua keinginan atau pendapat pribadi, dan memprioritaskan kepentingan kelompok. 
Gejala berikutnya adalah ilusi kebulatan suara, di mana hal ini melihat diam sebagai tanda persetujuan. Dimana pada saat pengambilan keputusan, ada perbedaan pendapat, dan apakah keheningan terjadi dan kemudian ditafsirkan sebagai bentuk persetujuan. Dari tanggapan kelompok informan, dapat disimpulkan bahwa kadangkadang itu memang terjadi, daripada terjadi konflik, lebih baik tidak mengatakan apaapa, juga untuk menjaga perasaan anggota lain, sehingga lebih baik tidak mengatakan apa-apa, meskipun kadang-kadang ada perdebatan, tetapi tidak untuk tingkat perdebatan yang panjang dan serius, tetap pada akhirnya anggota yang tidak setuju akan diam dan dapat menerima keputusan dari anggota.

Selanjutnya, gejala Self Mindguards, yang terjadi ketika individu melindungi kelompok dari informasi konfrontatif. Dalam gejala ini, anggota kelompok yang melindungi kelompok dari informasi yang merugikan, percaya bahwa mindguards bertindak dalam kepentingan terbaik kelompok. Selain para anggota kelompok masih memiliki kebebasan untuk menentukan pilihan, masing-masing, asalkan tidak ada yang keberatan, dan masih ada kebebasan anggota kelompok untuk bertindak dan pada kenyataannya tidak pernah terjadi sesuatu yang merugikan kelompok

Gejala terakhir adalah tekanan langsung pada pembangkang, di mana gejala ini mengandung arti menekan setiap anggota kelompok yang menyatakan pendapat, perspektif, atau komitmen yang berbeda dengan pendapat mayoritas. Gejala ini akan memberikan efek langsung pada anggota kelompok yang memberikan pikiran yang bertentangan dengan kelompok, misalnya dengan mencoba untuk memberikan pengertian kepada anggota kelompok yang punya pendapat yang berbeda,dan kemudian apabila tidak ada kesepakatan, mereka memilih untuk membatalkan kesepakatan sama sekali, juga tidak membatasi anggota untuk memberikan alasan, sehingga tidak perlu untuk memaksakan kehendak, dan tidak ada anggota yang merasa terpojok. Selama keputusan itu bukan merupakan keputusan yang penting, dalam arti bahwa jika hanya masalah kecil, tidak akan repotrepot, tetapi jika masalahnya adalah besar dan penting, anggota kelompok merasa perlu untuk berbicara dan mengekspresikan pendapat mereka.
Dari karakter yang terakhir ini, bisa ditarik beberapa kesimpulan, pertama, sensor diri adalah gejala yang terjadi pada semua kelompok, dengan alasan utama untuk menghindari konflik dan dengan niat positif yang positif untuk menjaga anggota tingkat egoism kelompok. Maka keheningan yang terjadi dan dianggap sebagai bentuk persetujuan juga terjadi, kadang-kadang dengan alasan untuk menghindari pendapat egois tersebut dan juga untuk menghindari konflik, maka perlu dilakukan. Untuk gejala berikutnya, maka dapat disimpulkan bahwa semua anggota kelompok tidak ditugaskan sebagai mindguards, tidak ada aturan untuk tidak diam dan mengingatkan kelompok dalam hal yang berkaitan dengan pengambilan keputusan. Kecuali dalam satu kelompok, Reg, yang juga secara tidak resmi memiliki beberapa orang yang kadang-kadang ingin mengingatkan anggota lain untuk berperilaku atau bertindak sesuai dengan norma-norma atau aturan kelompok.

Gejala terakhir, dua dari tiga kelompok sepakat bahwa tekanan tidak perlu dilakukan dalam bentuk apapun kepada anggota kelompok yang "membangkang", masingmasing anggota masih memiliki hak untuk berbicara dan memberikan alasan dan pendapat, kecuali satu kelompok, Reg, yang sedikit berbeda, yang merasa kelompok membutuhkan kesepakatan, meskipun untuk hal yang penting, menjaga anggota kelompok diberi kebebasan untuk berbicara dan mengekspresikan pendapat mereka.

Gejala Groupthink terjadi pada semua kelompok, dilihat dari masing-masing karakter Groupthink, semua kelompok mengalaminya. Namun, masih dapat dilihat bahwa Groupthink yang terjadi pada semua kelompok masih dalam situasi yang positif, kekompakan kelompok dan keyakinan tinggi dalam menjaga keutuhan kelompok tidak menyebabkan hal-hal negatif yang disebut Irving Janis.

Kemauan dan tekad untuk mempertahankan kesatuan dalam kelompok ini jelas terlihat dari jawaban yang diberikan oleh masing-masing kelompok. Rasa solidaritas yang tinggi dan kepercayaan di antara anggota dianggap sangat penting dan berfungsi untuk menyatukan cukup kuat dalam kelompok.

\section{Simpulan dan Saran}

Tingkat pendidikan tidak memengaruhi para anggota kelompok perempuan dalam 
mengambil keputusan. Tingkat pendidikan memang merupakan salah satu tolak ukur penting dalam proses pendewasaan seseorang, karena dengan tingkat pendidikan yang lebih tinggi, seseorang diharapkan dapat melakukan sesuatu yang lebih baik untuk diri mereka sendiri dan orang lain.

Hal tersebut dapat terjadi dikarenakan kompleksitas dan cara berfikir yang hampir sama dan tanpa mengalami perubahan yang berarti, yang seiring dengan bertambahnya tingkat pendidikan. Toleransi dan saling pengertian menjadi hal mendasar yang terus dapat dipelihara oleh masing-masing anggota kelompok sehingga keutuhan kelompok dapat tetap terjaga.

Komunikasi yang terjadi di dalam kelompok dipengaruhi oleh banyak hal, dalam penelitian ini disimpulkan bahwa perasaan saling dan memertahankan kelompok lebih menjadi dua faktor utama dalam pengambilan keputusan. hal ini terjadi pada semua anggota dalam penelitian ini, terlepas dari tingkat pendidikan yang berbeda, untuk semua faktor dalam pengambilan keputusan proses dilakukan dengan cara yang sama, dan hasilnya tidak berbeda, meskipun ada beberapa perbedaan kecil, seperti sikap yang lebih mementingkan diri sendiri yang ditunjukkan di tingkat pendidikan terendah, SMP, namun hal ini tidak terlihat terlalu dominan, karena sikap egois yang muncul tidak kuat dan dapat dipengaruhi.

Ada indikasi Groupthink tidak terjadi. Artinya, proses pengambilan keputusan yang terjadi pada masing-masing kelompok lebih ke arah yang positif, dan masih memertimbangkan perasaan dan pendapat dari anggota kelompok. Rasa kekompakan yang tumbuh cukup lama dan keinginan untuk menjaga integritas kelompok, membuat para anggota masih mencoba untuk mempertahankan eksistensi kelompok, semua perbedaan tetap dicoba untuk diselesaikan dengan cara yang paling diterima oleh semua anggota atau tidak ada keputusan yang diambil sama sekali.

Sikap positif dapat dipertahankan oleh para anggota kelompok dengan seiringnya perkembangan zaman dan perubahan lingkungan yang dialami oleh masing-masing anggota kelompok, dan berangkat dari latar belakang yang positif dalam komunikasi kelompok, diharapkan memiliki pengaruh positif juga dalam kehidupan para anggota kelompok tersebut.

\section{Daftar Pustaka}

Anna. L. K. (2013). Berada dalam Kelompok Bikin Wanita Terlihat Lebih Cantik .Diambil pada 16 Desember 2014 dari http://female. kompas.com/read/2013/11/02/1623286/ Berada.dalam.Kelompok. Bikin. Wanita. Terlihat.Lebih.Cantik

Aries, E. (1996). Men and Women in Interaction: Reconsidering the Differences: Reconsidering. Oxford University Press.

Bibby, R. W. (2009). The Emerging Millennials, How Canada's Newest Generation Responding to Change and Choice. Project Canada Books.

Carroll, J. B. (1993). Human Cognitive Abilities: A Survey of Factor-Analytic Studies. Press Syndicate of the University of Cambridge.

Daymon, C \& Holloway, I. (2011). Qualitative Research Methods in Public Relations and Marketing Communications. Routledge.

Haynes, N. M. (2012). Group Dynamics, Basic and Pragmatics for Practitioners, University Press of America.

Ierodiakonou. \& Charalambos. (2011). The Psychology of Aristotle, the Philosopher: A Psychoanalytic Therapist's Perspective. Karnac Book.

NN. Kebiasaan Aneh Wanita Yang Bikin Pria Heran. (2013). Diambil pada 16 Desember 2014. dari http://www.vemale.com/ relationship/love/27847-kebiasaan-anehwanita-yang-bikin-pria-heran.html

Raghubir, P. \& Valenzuela, A. (2009). MaleFemale Dynamics in Groups; a Field Study of the Weakest Link, Small Group Research, Sage.

Rucker. M. (2010). 9 Differences between the Male and Female Brain. Diambil pada 15 Desember 2014 dari http://www. brainfitnessforlife.com/9-differencesbetween-the-male-and-female-brain/

Shaffer. D.R, \& Kipp. K. (2010). Developmental Psychology: Childhood \& Adolescence, $8^{\text {th }}$ edition, Wadsworth Cengage Learning.

Sugarman, L. (2001). Life-span Development: Frameworks, Accounts and Strategies, Psychology. Press Ltd.

The Psychology Foundation of Canada. (2012). Straight Talk about Teens.

West, R. \& Turner, L. H. (2010). Introducing Communication Theory, Introducing Communication Theory, Analysis \& Application. 4th Edition. McGraw-Hill Higher Education. 